\title{
Crianças em Conflito com a Lei / Children in Conflict with the Law
}

https://doi.org/10.21814/uminho.ed.36.18

\section{Chandni Basu}

Institute of Sociology, University of Freiburg, Germany \& Institute of Development Studies Kolkata, India 



\section{Crianças em Conflito com a Lei}

Um número crescente de crianças, por todo o mundo, tem tido contacto com o sistema de justiça juvenil, enquanto agressoras. $O$ facto de estarem do lado errado da lei dota-os de uma identidade específica, a de crianças em conflito com a lei (CCL). 0 sistema de Justiça Juvenil é o mecanismo legal que atende os jovens que foram detidos por acusações de ofensas criminais. É distinto do sistema para adultos e criado especialmente para estes jovens, em termos de dispositivos e procedimentos judiciários. De acordo com a Convenção sobre os Direitos da Criança de 1989 (CDC), qualquer pessoa com idade entre os 0 e os 18 anos é elegível para obter a proteção da justiça juvenil e, assim, ser considerada uma criança em conflito com a lei com proteção especial neste sistema de justiça. Estas medidas protetivas estão fundadas no princípio de justiça restaurativa, sendo que a CDC harmoniza os princípios que todos os estados-membros devem seguir para implementar o mecanismo de justiça juvenil, quer em termos de dispositivos e provisões legais quer em termos de procedimentos administrativos. 0 termo crianças em conflito com a lei veio substituir nomenclaturas anteriores como jovens em conflito com a lei ou delinquência juvenil, procurando reduzir o peso da responsabilidade criminal dos jovens pelas suas ofensas que motivam um contacto com a lei. As atividades pelas quais poderão ser detidos incluem ofensas criminais como homicídio, violação, roubo e furto. Especificamente, mais rapazes são detidos como crianças em conflito com a lei, do que raparigas. As orientações da CDC definem diretivas para o funcionamento de centros de justiça juvenil e para a atuação policial na detenção de jovens que entram em contacto com a lei. $O$ envolvimento de crianças em ofensas criminais causa o pânico na sociedade em geral, como foi possível observar no caso do homicídio de James Bulger, que envolveu dois rapazes no Reino Unido, ambos com 10 anos de idade (Jenks, 2005, pp. 117-136). Estes incidentes deixam a descoberto uma imagem das próprias crianças como ameaças aos ideais da infância moderna, cristalizados na conotação da inocência. $O$ envolvimento em atos criminais por parte de jovens ultrapassa os parâmetros da ética normativa da infância e é, assim, considerado um desvio/transgressão, levando a que as crianças em conflito com a lei sejam consideradas desviantes. 
A história da infância moderna está amplamente relacionada com a construção do desvio moderno enquanto categoria colonial no século XIX (Basu, 2018). Tal construção foi feita juntamente com o mapeamento de definição da "periferia juvenil" pela administração colonial na sociedade nativa (Sen, 2005). Os reformatórios coloniais para o encarceramento de crianças das sociedades nativas foram uma configuração espacial importante que definiu a periferia juvenil, sendo grande parte destas crianças encarceradas pertencentes às secções marginais da sociedade nativa. Assim, estes reformatórios tornaram-se um lugar importante para o complexo mapeamento da delinquência e desvio juvenil. No conceito contemporâneo de justiça juvenil, as crianças em conflito com a lei têm direito a proteção judiciária especial, estando o sistema preparado para criar um ambiente amigável para os jovens apreendidos. Estes incluem dispositivos específicos como: audição de testemunho em salas por observação; audiência ou julgamento em sala com ambiente não formal; ausência de banco de testemunhas e nomenclaturas como Conselho em vez de Tribunal. Nas esquadras de polícia, algumas das provisões especiais para jovens incluem o não algemamento, o não aprisionamento, o reporte dos casos nos Conselhos de Justiça Juvenil imediatamente após a submissão da ocorrência ou uma reunião com agentes especializados para os jovens nas esquadras. A proteção jurídica para jovens detidos também se traduz no princípio da não retribuição. Isso pode traduzir-se por um período de probation, com intervenção comunitário a partir do momento da decisão condenatória. Este princípio traduz-se em atividades como serviços comunitários e a comunicação regular com o técnico indicado para esse efeito. Estas medidas pretendem libertar as crianças em conflito com a lei do peso da responsabilidade criminal pelas suas práticas de ofensas. Os perfis das crianças em conflito com a lei, provenientes sobretudo de locais desfavorecidos, chama a nossa atenção para a marginalidade social como um tema pertinente interligado com a transgressão em jovens (Basu, 2018). Neste ponto, a falta de escolaridade é apontada como um fator decisivo que tem impacto no envolvimento criminal dos jovens, sendo correlacionado com a concetualização da educação como capital cultural e como um indicador da infância moderna, juntamente com a formulação binária simultânea de desvio como uma ausência de infância. Um número crescente de crianças em conflito com a lei em sistemas da justiça juvenil em diferentes sociedades, recentemente, também destaca o conceito biológico baseado na idade para o conceito de menoridade legal. A complexidade da menoridade legal juntamente com a marginalidade permeia a realidade social das crianças em conflito com a lei, o que promove a relação dialética entre infância e desvio. 


\section{Children in Conflict with the Law}

A growing number of children as perpetrators is encountering an interface with the juvenile justice system (JJS) around the world. Being on the wrong side of the law gives them the identity as children in conflict with the law (CCL). JJS is the legal mechanism which supports these young people who are apprehended on charges of criminal offences. This is a separate legal mechanism set up specially to support apprehended young people. It remains distinct from the adult courts in terms of its infrastructural provisions and legalistic procedures. According to the guidelines of the United Nations Convention on the Rights of the Child 1989 (UNCRC) any person between 0-18 years of age is eligible to receive the protection of the juvenile justice mechanism and from then to be considered as children in conflict with the law for special legal protection once they interact with the JJS. These protective measures are founded on the principle of restorative justice. UNCRC standardizes the guidelines for setting up the juvenile justice mechanism in terms of its infrastructural provisions and administrative procedures for all member signatory states. The terminology children in conflict with the law has replaced earlier nomenclatures like juveniles in conflict with the law or juvenile delinquency. This is to release apprehended young people from the burden of criminal responsibility for their offences that bring me into contact with the law. The activities for which they could be apprehended include criminal offences ranging from murder, rape, burglary to pick pocketing. Notably, there are more younger boys than girls apprehended as children in conflict with the law. The UNCRC guidelines provide directives for the functioning of both the juvenile justice boards and the police in dealing with apprehended young people once they encounter the law. The involvement of children in criminal offences causes moral panic in society at large. This reaction can be seen in the case of James Bulger's murder by two ten-year-olds-boys in the UK (Jenks, 2005, pp.117-136). Such incidents starkly expose the image of children themselves as threats to the ideals of modern childhood based on the icon of innocence. Criminal engagements among young people therefore fall beyond the parameters of the normative ethics of childhood and are hence considered as deviance or transgressive behaviour. Children in conflict with the law are thus considered deviants. The history of modern childhood is densely interlinked with the construction of modern deviance as a colonial category in the nineteenth century (Basu, 2018). Such a construction was engineered along with the contour mapping of the "juvenile periphery" by the colonial administration in native society (Sen, 2005). Colonial reformatories for incarcerated children of the native society were an 
important spatial configuration which defined the juvenile periphery. These incarcerated children belonged mostly to the marginal sections of the native society. The colonial reformatory therefore became an important site where the complex entanglements of juvenile delinquency and deviance were demonstrated. Within the contemporary juvenile justice mechanism CCLs are entitled to special legal protection. JJS is geared towards providing a child-friendly atmosphere for apprehended young people. These include infrastructural facilities such as in-camera proceedings, "a drawing-room like atmosphere" at the juvenile justice board, no witness box or nomenclatures like board in place of courts. At the police station some of the special arrangements for young people include no handcuffing, no lockups, reporting of the case at the juvenile justice board immediately after the first information report is filed or appointments of special officers for young people at the police station. Legal protection for apprehended young people also translates into no retribution. Instead, they are mandated to complete a probation period of a stipulated time once found guilty. This includes activities like community service and regular reporting to the assigned probation officer. These measures are meant to release the children in conflict with the law from any burden of criminal responsibility for their unlawful offences. Profiles of children in conflict with the law, mostly from underprivileged locations, draw our attention to social marginality as a pertinent issue interlinked with transgression among young people (Basu, 2018). In this respect, lack of education is pointed out as one of the decisive factors which impacts the criminal involvement of young people. It is correlated with the conceptualization of education as cultural capital and as an indicator of modern childhood with the simultaneous binary formulation of deviance as a lack of childhood. Recently, the growing number of children in conflict with the law within the juvenile justice mechanism in different societies also problematizes the biological age- based concept of legal minority. The entangled complexity of legal minority along with marginality pervades the social reality of children in conflict with the law. This extends the dialectical relationship between childhood and deviance.

The views expressed herein are those of the author and do not necessarily reflect the views of the United Nations.

\section{Referências / References}

Basu, C. (2018). Ours or Theirs: Locating the 'Criminal Child' in relation to education in the postcolonial context of India. In A. Twum-Danso, M, Bourdillon \& S. Meichsner (Eds.), Global Childhoods Beyond the North-South Divide (pp. 57-79). London: Palgrave Macmillan.

Jenks, C. (2005). Childhood (2nd Ed.). London: Routledge.

Sen,S.(2005).Colonial Childhoods:TheJuvenilePeripheryofIndia,1850-1945.London:Anthem Press. 